\title{
VISUOMENĖS VAISTINĖSE TEIKIAMŲ PASLAUGŲ PRIEINAMUMAS JUDËJIMO NEGALIĄ TURINTIEMS MIESTO GYVENTOJAMS COVID-19 KARANTINO METU
}

\author{
Ingrida Romaškaitė, Regina Motienė, Danguolè Grūnovienė \\ Kauno kolegijos Medicinos fakultetas
}

Raktažodžiai: judèjimo negalia, farmacinè paslauga, neigalumas, visuomenès vaistinè.

\begin{abstract}
Santrauka
Pasaulyje kilus COVID-19 pandemijai, Lietuvos Respublikos Vyriausybė 2020 kovo 14 d. paskelbẻ karantiną valstybès mastu [7]. Dèl socialinio atsiribojimo, rizikos užsikrèsti COVID-19 ir galimų kliūčių naudotis sveikatos priežiūros paslaugomis, galèjo kilti kokybiškos farmacinès paslaugos gavimo problemų judejimo negalią turintiems gyventojams. Tyrimu siekta atskleisti visuomenės vaistinèse teikiamų paslaugų prieinamumą judèjimo negalią turintiems miesto gyventojams COVID-19 karantino metu. Duomenų rinkimo priemoné - stebèjimas. Stebètos 34 visuomenès vaistinès, esančios $\mathrm{X}$ mieste. Tyrimo tikslui pasiekti vykdyta apklausa pagal pasirinktus stebejjimo kriterijus. Nustatyti trys visuomenès vaistiniu prieinamumo judejjimo negalią turintiems gyventojams tipai: prieinama, riboto prieinamumo ir neprieinama. Gauti tyrimo rezultatai parodè, kad gyventojams, turintiems judejjimo negalią, didžioji dauguma visuomenès vaistinių prieinamos savarankiškai, daugiau nei dešimtadalis - riboto prieinamumo (i vaistinę gali patekti tik padedami asistento), o apie dešimtadalis - neprieinamos. Didžiausia vaistinių neprieinamumo problema yra pandusų stoka arba netinkamas jų įrengimas ir ribotos judejimo galimybės vaistinès viduje. Visose vaistinèse vadovaujamasi sveikatos apsaugos ministerijos informacija bei rekomendacijomis vaistinèms ir farmacijos specialistams dèl COVID-19 infekcijos ir kitų infekciniu ligų plitimo prevencijos, laikomasi socialinio atstumo, sudarytos sąlygos rankų dezinfekcijai. Judejjimo negalią turintiems gyventojams vaistinėse kyla sunkumų dèl rankų dezinfekavimo priemonių fizinio prieinamumo, skaidraus stiklo pertvaros konsultacijos metu riboja informacijos gavimą. Dauguma specialistu, teikdami farmacinę paslaugą, vaistinės pacientams skiria pakankamai
\end{abstract}

dèmesio, konsultuoja dèl racionalaus vaistinių preparatų vartojimo, COVID-19 prevencijos ir kitais klausimais. Mažiau nei dešimtadalis specialistų nesuteikè kokybiškos farmacinès paslaugos neigaliojo vežimèliuose atvykusiems gyventojams: elgèsi abejingai, nekantriai, buvo nedèmesingi.

\section{Ivadas}

Saugus, efektyvus, racionalus vaistų vartojimas leidžia visuomenei optimaliai valdyti ekonominius išteklius. LR farmacijos įstatymas apibrèžia farmacinès paslaugos sampratą: „Farmacinè paslauga - vaistineje farmacijos specialistų teikiama paslauga, apimanti receptų tikrinimą, vertinimą, nereceptinių vaistinių preparatų parinkimą, farmacinès informacijos apie vaistinius preparatus teikimą gyventojams, sveikatos priežiūros ir farmacijos specialistams, taip pat jų konsultavimą" [1]. Kiekvienas pacientas visuomenès vaistineje tikisi ne tik įsigyti vaistini preparatą, vaistinių prekių, bet ir gauti kokybišką farmacinę paslaugą. Vaistiniai preparatai, vaistinių prekès nèra ịprastinès, tinkamam jų pasirinkimui reikia turèti žinių. Netinkamai pasirinktas vaistinis preparatas, dozè ar vartojimas gali ne tik nepadèti pasveikti, bet ir pakenkti [2].

Tarptautinès farmacijos federacijos rekomendacijose nurodoma, kad ,gydytojai, farmacijos ir kiti sveikatos priežiūros specialistai kartu su vaistinès pacientais priimtų sprendimus, susijusius su medikamentiniu gydymu. Siūlydami ivvairius gydymo būdus, turètų aptarti su vaistinès pacientu ir leisti jam nuspręsti, koks gydymo būdas priimtiniausias" [3]. Pacientai ị vaistinę ateina ịsigyti gydytojo išrašytų receptinių vaistinių preparatų, pasikonsultuoti dèl receptinių ir nereceptinių vaistų vartojimo, ar galimo šalutinio poveikio; kita grupe pacientų, turinčių judèjimo negalią ir pasitikinčių farmacijos specialistais, $\mathfrak{i}$ visuomenès vaistinę ateina dèl ìvairių sveikatos būklès klausimų ir vaistinių prekių įsigijimo [4]. Asmenys, turintys judejjimo negalią, dažnai vartoja daugiau vaistinių preparatų bei vaistinių prekių nei kiti, todèl 
patiria daugiau sunkumų, susijusių tiek su vaistų vartojimu, tiek bendraudami su paslaugą teikiančiais farmacijos specialistais [5]. Nacionalinès neigaliujų socialinès integracijos programos igyvendinimo veiksmų plane numatyta priemonè, îpareigojanti atlikti savivaldybėms priklausančių pirminès sveikatos priežiūros įstaigų, socialinès paramos skyrių, socialinių paslaugų centrų pritaikymo neigaliesiems ịvertinimą ir parengti rekomendacijas pritaikyti neigaliujų reikmèms nepritaikytus statinius [6].

2020 m. kovo 14 d. Lietuvos Respublikos Vyriausybè visoje šalies teritorijoje paskelbė karantiną [7]. Atsižvelgdamas i $2020 \mathrm{~m}$. kovo 14 d. LR Vyriausybès nutarimą (Nr. 207) Dèl karantino Lietuvos Respublikos teritorijoje paskelbimo [7] ir Pasaulio sveikatos organizacijos rekomendacijas, Lietuvos Respublikos sveikatos apsaugos ministras - valstybès lygio ekstremaliosios situacijos valstybès operacijų vadovas $2020 \mathrm{~m}$. kovo $16 \mathrm{~d}$. prièmė sprendimą (Nr. V-378) Dèl COVID-19 ligos (koronaviruso infekcijos) valdymo priemonių vaistinèms, kuriuo nurodè visoms vaistinèms organizuoti gyventojų srautus, atsižvelgiant ị vaistinès plotą, siekiant išvengti grūsčių, sudaryti galimybę tinkamai rankų higienai, prie ịejjimo ị vaistinès oficiną paskelbti informaciją, atkreipiančią dèmesị i gyventojų asmens higienos laikymąsi (rankų higiena, kosèjimo, čiaudejjimo etiketas). Skatinti gyventojus eilèse prie kasų ar savitarnos kasų laikytis saugaus, ne mažesnio kaip $1 \mathrm{~m}$ atstumo, pagal galimybes vaistinėms riboti vienam gyventojui parduodamą dezinfekcinių priemonių kiekị taip, kad jos būtų prieinamos kuo didesniam gyventojų skaičiui. Nuspręsta imtis maksimalių priemonių, siekiant apsaugoti vaistinių darbuotojus nuo užsikrėtimo

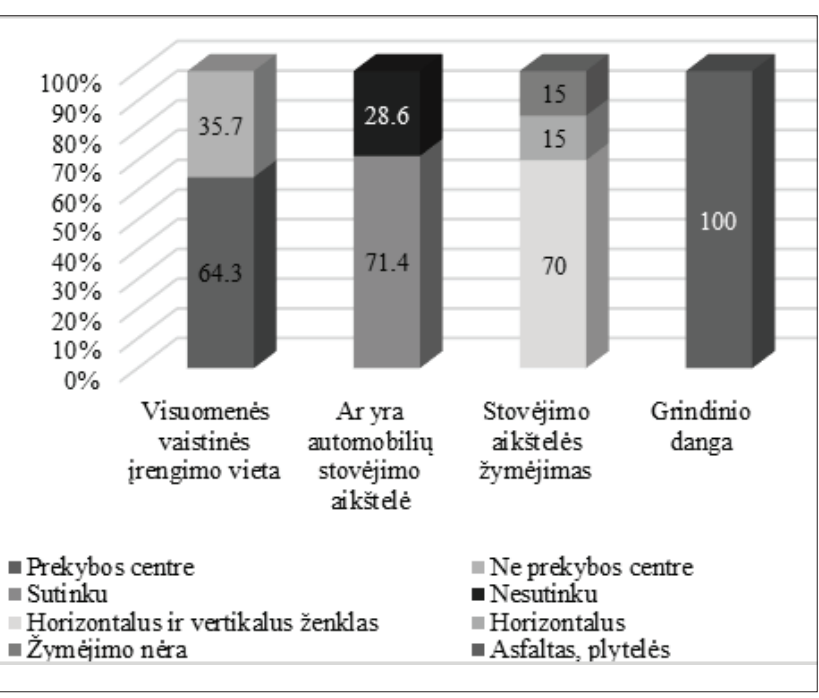

1 pav. Visuomenės vaistinių prieinamumo judèjimo negalią turintiems gyventojams tipai ir infrastruktūra (įrengti pertvaras tarp vaistinių darbuotojų ir gyventojų, aprūpinti vaistinių darbuotojus apsaugos priemonėmis ir kt.) [8]. Vykdant šį sprendimą visuomenès vaistinèse, galèjo kilti kokybiškos farmacinès paslaugos gavimo problemu judejjimo negalią turintiems gyventojams.

Tyrimo tikslas - atskleisti visuomenès vaistinèse teikiamos farmacinès paslaugos prieinamumą COVID-19 karantino metu judejjimo negalią turintiems miesto gyventojams.

\section{Tyrimo medžiaga ir metodai}

Tyrimo metodas - struktūruotas stebejimas. Pasirengimo etapo metu sudarytas tyrimo planas ir nustatytas optimalus stebimų požymių skaičius. Stebèjimo tikslas - $34 \mathrm{X}$ miesto visuomenès vaistinių prieinamumas neiggaliesiems. Valstybinès vaistų kontrolès tarnybos duomenimis, $\mathrm{X}$ mieste ịsikūrusios 37 visuomenès vaistinès, stebèta 34 vaistinių prieinamumo galimybès, 3 vaistinèse stebėjimui vykdyti nebuvo sudarytos sąlygos. Duomenys buvo užrašomi pagal prieš stebejjimą sukurtas kategorijas, iš anksto parinkus teoriškai apibrèžtus aspektus. Taikyti vienodi kriterijai. Stebejjimo metu gauti duomenys palyginti.

Sudarant stebejjimo kriterijus, suformuluoti 32 klausimai. Kriterijui vertinti pateikti 3 klausimai, padedantys įvertinti visuomenès vaistinèse teikiamų paslaugų prieinamumą judejjimo negalią turintiems miesto gyventojams: išorinè ir vidiné visuomenės vaistinių aplinka, farmacijos specialisto reakcija ị vaistinès pacientą, atvykusị neiggaliojo vežimèliu. Tyrimas atliktas naudojant iš anksto parengtą visuomenès vaistinių vertinimo anketą. Išorinei aplinkai vertinti buvo taikomi automobiliu aikštelès pritaikymo neigaliesiems kriterijai: kliūtys prie ięjimo, grindinio kokybè, patekimas i objektą, durų pritaikymas ir kt. Vidaus aplinkai nustatyti

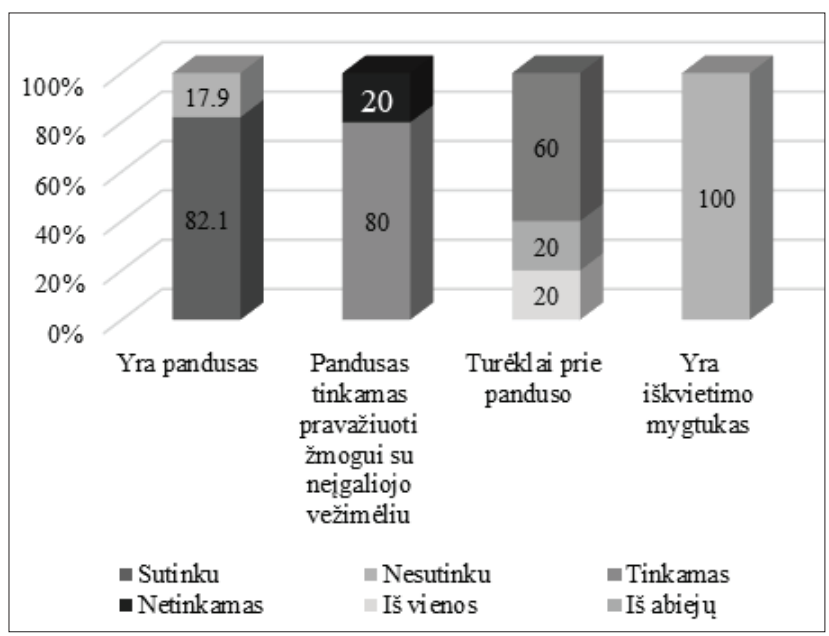

2 pav. Panduso ịrengimas ir pritaikymas judejjimo negalią turintiems gyventojams 
buvo vertinama galimybė judèti vaistinès viduje, savitarnos skyriaus buvimas, farmacijos specialisto teikiama farmacinè paslauga, reakcija ị vaistinès pacientą neịgaliojo vežimèlyje, konsultaciné veikla ir kt. Tyrimo duomenų analizei naudoti aprašomosios statistikos metodai. Gauti duomenys apdoroti ir grafinè analizè atlikta naudojant Microsoft Excel programą.

\section{Tyrimo rezultatai}

Atlikta visuomenès vaistinių fizinio prieinamumo neigaliesiems analizè: įvertintas patalpų ir ịrengimų tinkamumas, vaistinès aplinkos pritaikymas judèjimo negalią turintiems gyventojams. Atliktas farmacijos specialisto reakcijos į vaistinès pacientą neiggaliojo vežimèlyje stebėsenos vertinimas.

Tyrimo duomenys atskleide visuomenès vaistinių fizinio prieinamumo judejjimo negalią turintiems gyventojams tipus ir infrastruktūrą (1 pav.). Dauguma (64,3 proc.) X mieste aplankytų vaistinių yra įrengtos prekybos centruose, daugiau nei trečdalis (35,7 proc.) - kitose patalpose. Didžioji dalis $(71,4$ proc.) X mieste aplankytų visuomenès vaistinių turi automobilių aikšteles, kita dalis $(28,6$ proc.) neturi. Tai didelè problema, nes neịgaliojo vežimèliu sudètinga ịveikti reikiamą atstumą. Dauguma (70 proc.) aikštelių, pritaikytų neigaliujų automobiliams, paženklintos horizontaliai ir vertikaliai. Kai kurių (15 proc.) paženklinta danga, kai kurios (15 proc.) - nepaženklintos, tačiau visų aikštelių grindinio danga buvo iš asfalto arba trinkelių (1 pav.).

Apibendrinant fizinio vaistiniu prieinamumo galimybes judejjimo negalią turintiems gyventojams, nustatyti trys visuomenès vaistinių prieinamumo tipai: prieinama, riboto prieinamumo ir neprieinama. Gauti tyrimo rezultatai parodè, kad didžioji dauguma visuomenès vaistinių, kuriose lankèsi judèjimo negalią turintys gyventojai, jiems buvo prieinamos savarankiškai, daugiau nei dešimtadalis - riboto

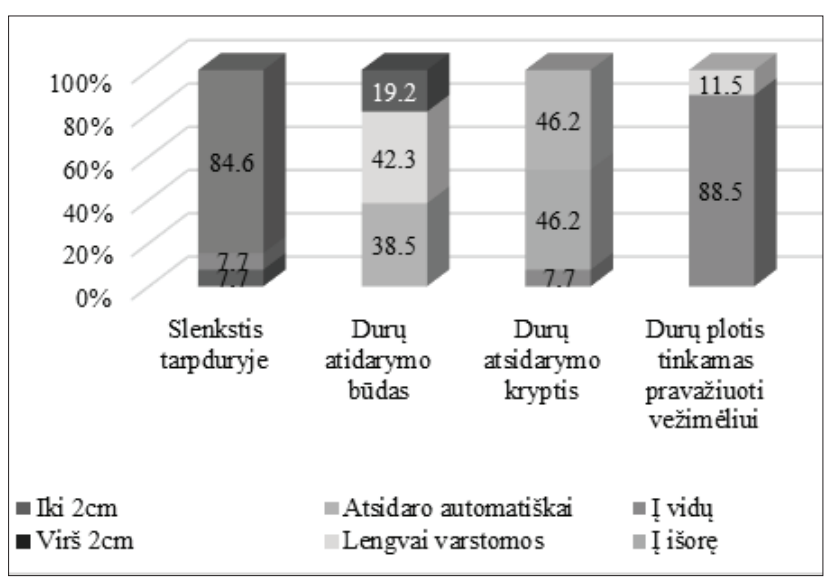

3 pav. Galimybès judèjimo negalią turintiems gyventojams patekti i vaistinès vidų prieinamumo (ị vaistinę pateko tik padedamas asistento), dešimtadalis vaistinių buvo neprieinamos judejjimo negalią turintiems gyventojams.

Buvo ịvertintos gyventojų patekimo ị vaistinę galimybès: panduso įrengimas ir pritaikymas judejjimo negalią turintiems gyventojams, turèklų ir iškvietimo mygtuko įrengimas bei slenksčio ir durų atitikimas neigaliesiems su vežimèliu (2 pav.). Nustatyta, kad daugelyje ( 82,1 proc.) aplankytų vaistinių nebuvo panduso, tačiau dauguma jų įsikūrusios prekybos centruose, tad pandusai ịvažiuoti ị visuomenès vaistinę šiuo atveju nebūtinai reikalingi. Dauguma (80 proc.) įrengtų pandusų yra tinkami važiuoti neịgaliojo vežimèliu, tačiau daugiau kaip pusei (60 proc.) neįrengti turèklai. Nei vienoje aplankytų visuomenès vaistinių nebuvo iškvietimo mygtuko. Šis elementas yra būtinas, nes palengvina neigaliesiems išsikviesti farmacijos specialistą, kuris padetų patekti ì vaistinę (2 pav.).

Slenksčių vaistinių tarpduryje dažniausiai (84,6 proc.) nèra, apie dešimtadalyje buvo iki $2 \mathrm{~cm}$ slenkstis. Kuo aukštesnis slenkstis tarpduryje, tuo didesné tikimybė, kad gyventojas neigaliojo vežimèlyje negalès savarankiškai ịvažiuoti ị vaistinę ir bus reikalinga asistento pagalba (3 pav.). Tiriamujjų visuomenès vaistinių durys atsidaro įvairiai: į šonus $(46,2$ proc.), i i išorę ( 46,2 proc.), lengvai varstomos ( 42,3 proc.), automatinès (38,5 proc.). Vertinant duris, buvo kreipiamas dèmesys i jų ploti, nes per siauros durys gali tapti viena iš kliūčių, dèl kurios judejjimo negalią turintis gyventojas negalès patekti į vaistinę. Dauguma (88,5 proc.) durų atitiko reikalavimus, buvo tinkamo pločio įvažiuoti neigaliojo vežimèliu.

Apibendrinant gyventojų patekimo ị vaistines galimybes, galima teigti, kad aplankytose visuomenès vaistinèse nèra iškvietimo mygtukų, daugumoje nebuvo tinkamai ịrengtų

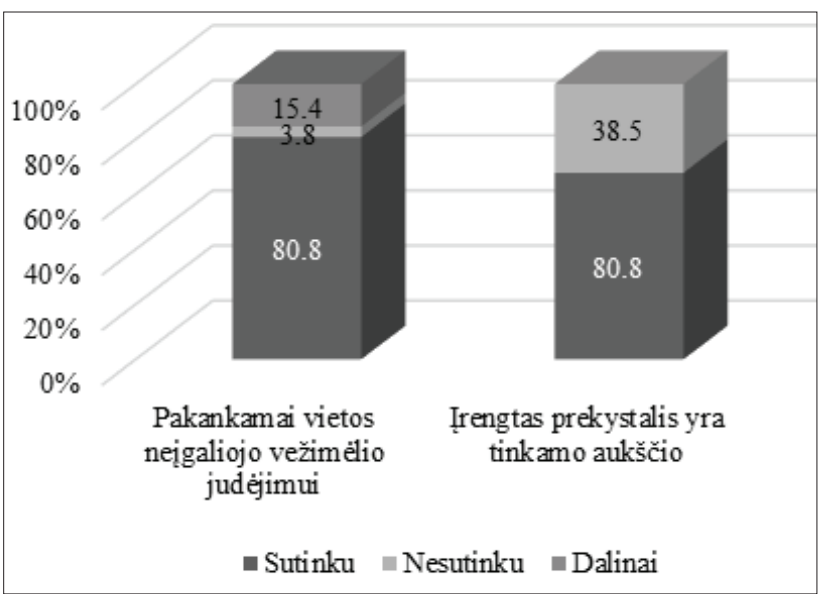

4 pav. Vaistinès vidaus aplinkos pritaikymas judèjimo negalią turintiems gyventojams 
pandusų. Durys visur lengvai varstomos, daugumos plotis atitiko ịvažiavimo ị visuomenès vaistinę neịgaliojo vežimèliu reikalavimus.

Labai svarbu, kad visuomenès vaistinèse teikiamos paslaugos būtų prieinamos gyventojams neigaliojo vežimėlyje, todèl buvo vertinama vidinè visuomenès vaistinių aplinka. Tyrimo duomenys parode, kad didžiojoje dalyje ( 80,8 proc.) visuomenès vaistinių pakanka vietos judèti neigaliojo vežimèlyje. İrengti tinkamo aukščio prekystaliai ( 80,8 proc.) neigaliujų aptarnavimui (4 pav.).

Vertinant visuomenès vaistinių vidaus pritaikymą judèjimo negalią turintiems asmenims COVID-19 karantino metu, nustatyta, kad visose stebètose $\mathrm{X}$ miesto visuomenès vaistinèse sudaryta galimybè rankų dezinfekcijai ir yra informacija, atkreipianti gyventojų dèmesị i asmens higienos reikalavimų laikymąsi. Labai mažoje dalyje vaistinių judèjimo negalią turintiems gyventojams kilo sunkumų dèl dezinfekavimo priemonių rankoms fizinio prieinamumo ar bandymo tinkamai dezinfekuoti rankas; skaidraus stiklo pertvaros ribojo informacijos gavimą konsultacijos metu (6 pav.). Visose stebètose $\mathrm{X}$ miesto visuomenès vaistinèse irengtos pertvaros tarp vaistinès pacientų ir farmacijos specialistų, farmacijos specialistai dèvejo apsaugines kaukes ir apsaugines pirštines. Beveik visi (96 proc.) laukiantieji prie kasų laikèsi saugaus, ne mažesnio kaip $1 \mathrm{~m}$ atstumo (5 pav.).

Tyrimo metu nustatyta, kad visose stebètose $\mathrm{X}$ miesto visuomenès vaistinėse farmacijos specialistai teikè kokybišką farmacinę paslaugą: vykdẻ gydytojo išrašytų receptų kontrolę, vertinimą, parinko nereceptinius vaistinius preparatus, teikè farmacinę informaciją apie vaistinius preparatus, îspèdami apie vaistų nesuderinamumą, aiškino vaistų laikymo

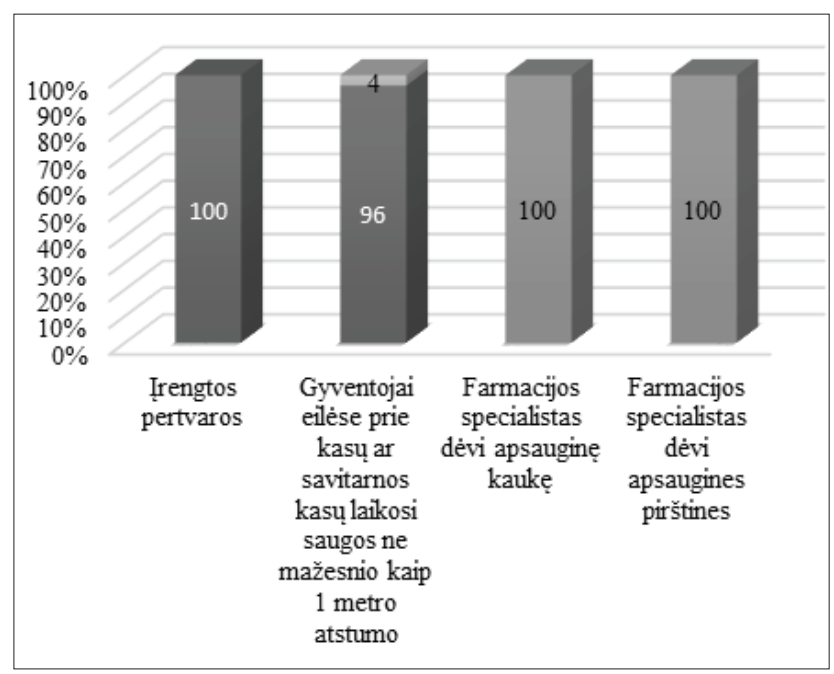

5 pav. Vaistinès vidaus pritaikymas COVID-19 karantino metu judèjimo negalią turintiems gyventojams sąlygas, patarẻ ligų ir COVID-19 prevencijos klausimais. Didžioji dauguma farmacijos specialistų su gyventojais, turinčiais judejjimo negalią, bendravo maloniai, kantriai teikè farmacinę paslaugą. Mažiau nei dešimtadalis elgèsi abejingai, buvo nekantrūs, neatidūs, teikè nekokybišką farmacinę paslaugą gyventojams, atvykusiems neịgaliojo vežimèliuose (6 pav.).

Apibendrinant galima teigti, kad atsižvelgiant i vaistinès plotą, sudarant galimybę rankų higienai, prie kasų ar savitarnos kasų laikantis saugaus, ne mažesnio kaip $1 \mathrm{~m}$ atstumo, kilo sunkumų judèti neigaliojo vežimèliu, skaidraus stiklo pertvaros kèlè sunkumų gauti kokybišką farmacinę paslaugą, nors visi farmacijos specialistai ją teikè tinkamai: konsultavo apie vaistinius preparatus, vaistinių prekes, jų vartojimą, įspejo apie vaistų nesuderinamumą, paaiškino vaistų laikymo sąlygas, patare ligų, COVID-19 prevencijos klausimais. Vaistinès tinkamai paruoštos socialiniam kontaktui išlaikyti, sudarytos sąlygos rankų dezinfekcijai. Tyrimo metu nustatytos pagrindinès dalies vaistinių neprieinamumo judejjimo negalią turintiems gyventojams problemos: pandusų, judëjimo galimybès vaistinès viduje nebuvimas, per aukšti prekystaliai, neịrengti iškvietimo mygtukai. Atlikto tyrimo rezultatai atskleide, kad mažoje dalyje $\mathrm{X}$ miesto visuomenès vaistinių judejjimo negalią turintiems gyventojams COVID-19 karantino metu trūko kai kurių vaistinès teikiamų paslaugų prieinamumo ir kokybès.

\section{Išvados}

1. Nustatyti trys visuomenès vaistinių prieinamumo judejimo negalią turintiems gyventojams tipai: prieinama, riboto prieinamumo ir neprieinama. Gauti tyrimo rezultatai parodè, kad gyventojams, turintiems judejjimo negalią, di-

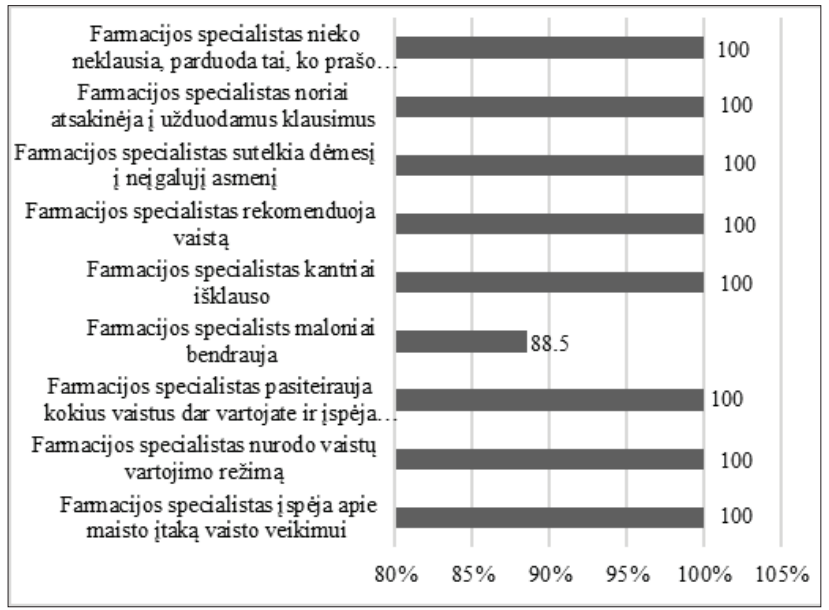

6 pav. Farmacinès paslaugos teikimo kokybė judejjimo negalią turintiems gyventojams COVID-19 karantino metu 
džioji dauguma visuomenès vaistinių prieinamos savarankiškai, daugiau nei dešimtadalis - riboto prieinamumo (i vaistinę gali patekti tik padedami asistento), o apie dešimtadalis - neprieinamos. Didžiausia neprieinamumo problema yra pandusų stoka arba netinkamas jų ịrengimas ir ribotos judejjimo galimybès vaistinès viduje.

2. Visose vaistinèse vadovaujamasi sveikatos apsaugos ministerijos informacija bei rekomendacijomis vaistinèms ir farmacijos specialistams dèl COVID-19 infekcijos ir kitu infekcinių ligų plitimo prevencijos, laikomasi socialinio atstumo, sudarytos sąlygos rankų dezinfekavimo sąlygos.

3. Judejjimo negalią turintiems gyventojams kyla sunkumų dèl rankų dezinfekavimo priemonių fizinio prieinamumo. Skaidraus stiklo pertvaros riboja informacijos gavimą konsultacijos metu. Farmacijos specialistai, teikdami farmacinę paslaugą, vaistinès pacientams skiria pakankamai dèmesio, konsultuoja dèl racionalaus vaistinių preparatų vartojimo, COVID-19 prevencijos ir kitais klausimais. Mažiau nei dešimtadalis specialistų buvo abejingi, nekantrūs, nedèmesingi, teikè nekokybišką farmacinę paslaugą judèjimo negalią turintiems gyventojams, atvykusiems neigaliojo vežimèlyje.

\section{Literatūra}

1. Lietuvos Respublikos neigaliųų socialinès integracijos įstatymas Nr. I-2044. Lietuvos Respublikos Aukščiausioji Taryba - Atkuriamasis Seimas, 1991.

2. Andrulis M. Vaistinių prieinamumas fizinę negalią turintiems asmenims. Magistro baigiamasis darbas. LSMU, 2017:57.

3. Tarptautinès farmacijos federacijos rekomendacijos farmacijos specialistams. http://www.fip.org/file/4428.

4. Lietuvos Respublikos sveikatos apsaugos ministro $2003 \mathrm{~m}$. sausio 7 d. įsakymas Nr. V-7 Dẻl vaistinių patalpų ir ịrengimų reikalavimų patvirtinimo. Valstybės žinios, 2003-01-10, Nr. 3-77.

5. Kamarei DK, Syengo FK, Osuga B, Adoyo M. Physical barriers influencing accessibility of healthcare services by the physically challenged persons: a case study of Likoni sub-county, Mombasa county. Strategic Journal of Business \& Change Management 2016;3(3)17:279-288.

6. LR socialinès apsaugos ir darbo ministro $2018 \mathrm{~m}$. gegužès 10 d. ịsakymas Nr. A1-207 Dèl Lietuvos Respublikos socialinès apsaugos ir darbo ministro $2015 \mathrm{~m}$. birželio $25 \mathrm{~d}$. ịsakymo Nr. A1-381 „Dèl nacionalinès neiggaliujų socialinès integracijos 2013-2019 metu programos iggyvendinimo 2016-2018 metu veiksmų plano patvirtinimo" pakeitimo. Lietuvos Respublikos socialinès apsaugos ir darbo ministerija, TAR, 2018-05-10, Nr. 7582.

7. Lietuvos Respublikos Vyriausybès $2020 \mathrm{~m}$. kovo $14 \mathrm{~d}$. Nutarimas Nr. 207 Dèl karantino Lietuvos Respublikos teritorijoje paskelbimo. TAR, 2020-03-14, Nr. 5466.

8. Lietuvos Respublikos sveikatos apsaugos ministro - valstybès lygio ekstremaliosios situacijos valstybès operacijų vadovo 2020 m. kovo 16 d. Sprendimas Nr. V-378 Dèl Covid-19 ligos (koronaviruso infekcijos) valdymo priemonių vaistinems. TAR, 2020-03-16, Nr. 5536.

\section{ACCESS TO PUBLIC PHARMACY SERVICES FOR RESIDENTS IN CITY X WITH MOBILITY IMPAIRMENT DURING THE COVID-19 QUARANTINE \\ I. Romaškaitè, R. Motienė, D. Grūnovienè}

Keywords: mobility impairment, pharmaceutical services, disability, public pharmacy.

Summary

One of the most important goals of professionals in many fields is implementation of strategies that make services and information accessible to all citizens. In order to ensure that every resident has access to pharmaceutical services, the Law on Pharmacy of Lithuania and the supplementary legislation states that "a legal entity wishing to obtain a pharmacy license, must operate in suitable premises and use suitable and sufficient equipment, and the premises must be able to accommodate people with disability." The National Act outlining the implementation of the social integration programme aimed at people with disabilities includes three different measures related to ensuring physical access to the facilities. The third measure obliges „to carry out an assessment of the adaptation of municipal health care institutions, primary health care institutions, social support and social service centers to people with disability, and following this assessment, to make the necessary conclusions and recommendations aimed at the adaptation of buildings that do not meet the needs of the disabled members of the public". As a result of the global Covid-19 pandemic, the Government of Lithuania announced nationwide quarantine on March 14, 2020. Residents with mobility impairment are at higher risk of contracting Covid-19 due to hygiene procedures, social distancing and obstructions to access to healthcare services.

The aim of the research was to reveal the availability of services provided by public pharmacies to the residents of city $\mathrm{X}$ with mobility impairment during the Covid-19 quarantine. During the study, 34 public pharmacies located in city $\mathrm{X}$ were examined. Observation was used as data collection method. In order to achieve the objective of the research, a survey that followed pre-established observation criteria was carried out. The major problem associated with accessibility to pharmacies and identified in this research was the lack of ramps or their proper installation as well as limited mobility opportunities inside pharmacies. Covid-19 preventive measures are applied in pharmacies in accordance with the government recommendations: social distancing is maintained, conditions for hand disinfection are met, but the public has difficulty accessing hand sanitisers, clear glass partitions restrict obtaining information during consultation. When providing services, pharmacists attend to the patients and advise them on rational use of medicinal products, Covid-19 prevention and other issues; however, under ten percent demonstrated indifference, impatience, inattentiveness, provided poor quality pharmaceutical service for members of the public in wheelchairs.

Correspondence to: regina.motiene@go.kauko.lt

Gauta 2020-10-29 